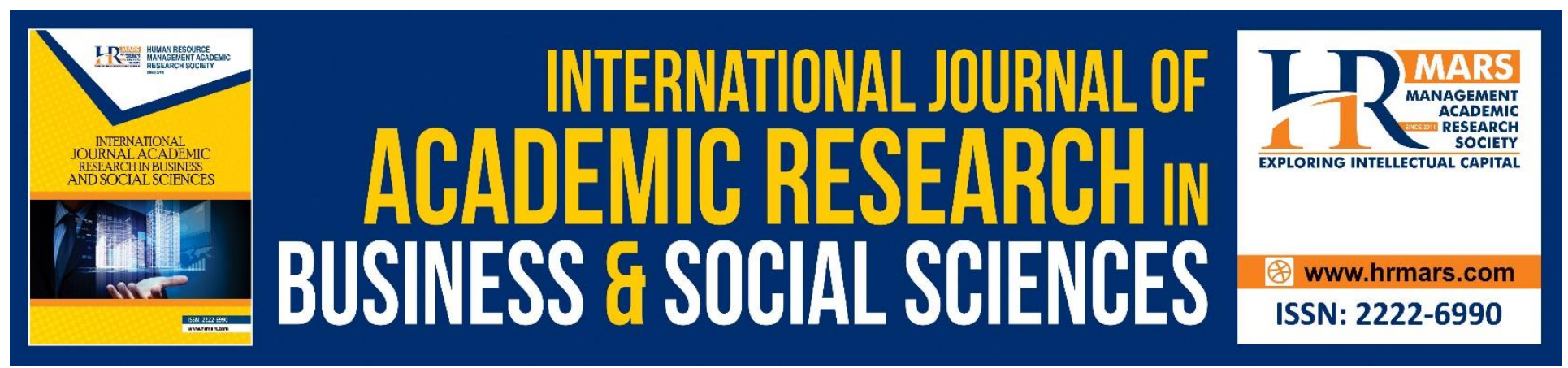

\title{
The Holy See's Commitment to Protect Unaccompanied Children on the Move
}

\author{
Maria Indira Aryani
}

To Link this Article: http://dx.doi.org/10.6007/IJARBSS/v9-i3/5701

DOI: $\quad 10.6007 /$ IJARBSS/v9-i3/5701

Received: 29 Jan 2019, Revised: 20 Feb 2019, Accepted: 06 March 2019

Published Online: 18 March 2019

In-Text Citation: (Aryani, 2019)

To Cite this Article: Aryani, M. I. (2019). The Holy See's Commitment to Protect Unaccompanied Children on the Move. International Journal of Academic Research in Business and Social Sciences, 9(3), 411-419.

\section{Copyright: (C) 2019 The Author(s)}

Published by Human Resource Management Academic Research Society (www.hrmars.com)

This article is published under the Creative Commons Attribution (CC BY 4.0) license. Anyone may reproduce, distribute, translate and create derivative works of this article (for both commercial and non-commercial purposes), subject to full attribution to the original publication and authors. The full terms of this license may be seen at: http://creativecommons.org/licences/by/4.0/legalcode

Vol. 9, No. 3, 2019, Pg. 411 - 419

Full Terms \& Conditions of access and use can be found at http://hrmars.com/index.php/pages/detail/publication-ethics 


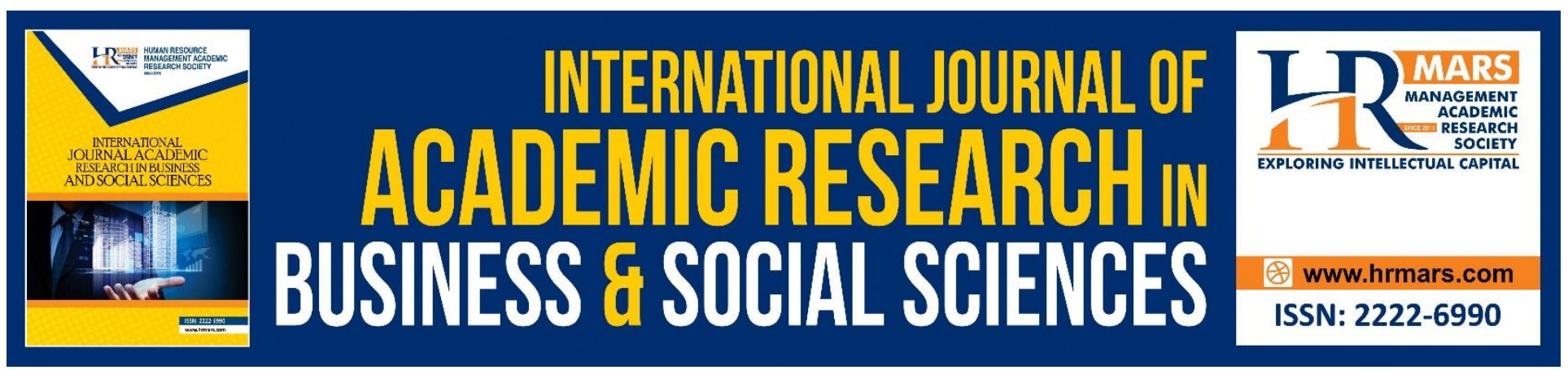

\title{
The Holy See's Commitment to Protect Unaccompanied Children on the Move
}

\author{
Maria Indira Aryani \\ Universitas Pembangunan Nasional “Veteran” Jawa Timur, Indonesia. Department of International \\ Relations, Faculty of Social and Political Sciences. Surabaya. Indonesia
}

\begin{abstract}
Background: Unaccompanied children on the move are the most vulnerable group in the refugee criteria because they move without the protection of parents as well as family members. They are the most fragile because they are often invincible, voiceless and they are faced to great risks such as human traffickers, sexual predators and other persons with harm. With the escalating conflict in several part of the world, there is a growing number of unaccompanied children on the move and too few being done to accommodate them. Objective: This paper is trying to see how the Holy See as a transnational actor tries to promote a better care for the refugees and providing better treatment and protection for unaccompanied children on the move. Results: The Holy See has been promoting social cooperation through solidarity and shared responsibility to protect the unaccompanied children on the move using its transnational influence. Conclusion: With its unique transnationality, the Holy See is working as the role of mediation between different cultures and socio political system to better protect the fundamental rights of unaccompanied children on the move.
\end{abstract}

\section{Introduction}

On September 3rd, 2015 the world was shocked by a horrific image of a washed ashore body of a three-year-old Syrian refugee, named Alan Kurdi on the beach near Bodrum, Turkey. Alan Kurdi drowned while crossing Mediterranean Sea with his parents, trying to flee Syria. The case of Alan Kurdi shed a new light on the case of refugee crisis, and most importantly, his tragic death brought upon a seemingly forgotten issue that children are the most vulnerable group of refugees. The number of child refugee increased dramatically with the escalating instability throughout the world, especially in the Middle East and Africa regions. While fleeing, children are often left unaccompanied by their adult relatives, posing a greater threat to an already vulnerable child refugee.

Since the death of Alan Kurdi, more attentions are put to ensure the wellbeing of unaccompanied children on the move. One of the actors that have been increasing its effort on protecting them is the 
Holy See. Since 2015, the Holy See has been actively promoting better protections and treatments for those children through various international forums both as a special political entity and as an international religious entity. The dual status allows the Holy See to have a more effective impact in promoting a better care for those children. This article is aimed at explaining how does the Holy See's unique transnationality can be more effective in promoting a better protection and treatment for the unaccompanied children on the move. The case of unaccompanied children on the move in this article is focused during the refugee crisis caused by the increasing instability in the Middle East from 2014 to 2017 where these children are then seeking asylum in the Europe as the bordering region.

\section{Methodology}

Unaccompanied children on the move, or sometimes referred to as unaccompanied migrant children, is a term used in the 1989 Convention of the Rights of the Child to describe children that is separated from their parents or other adult relatives and are not being cared for by an adult responsible in doing so (IOM, 2011). Later in 2008, UNICEF categorizes the -children on the movell as migrating children to another country searching for opportunities without prior authorization, exploited children through trafficking and children fleeing dangerous situation to seek asylum (Boland, 2010). Unaccompanied children on the move then is used to point a specific category in the refugee group as children fleeing dangerous situation to seek asylum without supervision from their parents or any adults legally responsible for their well-being. In this article, the use of the terms children will then refer to this specific category.

In recent years, the number of these specific groups increases significantly in accordance with the deteriorating situation in the Middle East. With the refugees' surge in the neighbouring region, also came the surge of these children. According to the Eurostat (Eurostat, 2016), the surge of refugees in Europe began in 2015 with over a million Middle Eastern seek for an asylum. The number kept increasing with the estimated 1,25 million more refugees came to Europe in 2016. This number is highly significant compared to what was recorded in 2014 where only 216,000 refugees came for shelter and there are only 23,160 unaccompanied children on the move (UNICEF, 2015). As recorded in 2015 and 2016, out of 2.5 million, 29\% of them are children and approximately 176,000 of them are considered to be unaccompanied migrant children. The majority of these children are adolescent boys in the age of 12 to 17. It was estimated that 6 out of 10 refugees in Europe are coming from Syria, Afghanistan and Iraq. The number of refugees coming to Europe is showing an increase, also the relative proportion of child refugee.

The growing number of unaccompanied children on the move has brought new concerns about the well-being of child refugees in their attempt to seek a better living environment. There are more threats to these children since they are moving cross borders without proper supervision. These children are more vulnerable to sexual violence, sexual exploitation, and trafficking (European Comission, 2016). During their migratory journey, these children are also prone to robbery and the accusation of petty crimes to keep themselves alive (IOM, 2011). They also have to overcome serious physical challenges, illnesses, injuries and even death while trying to cross difficult terrains or rough seas (IOM \& UNICEF, 2015). According to Monsignor Robert Vitillo, Secretary General to the International Catholic Migration Commission, these children also face great risks of being a victim of organ harvesting syndicate, child labor and early marriage phenomenon (Schlein, 2017). 
These threats are faced not just when the children are on the move, but also when they are at the detention centre in the destination country. Detention centre is a very dangerous environment for these children since there are no proper health care, education or even housing facilities. The use of detention centres in dealing with child refugees especially unaccompanied children on the move have caused a great debate in this recent years. Children and adult detainees are put in the same place. In here, those children are left to fend for themselves, they are voiceless without any access to legal or other appropriate assistance (Bhabha, 2016). Children under the age of 18 are not considered legal to make their own decision or to apply for as asylum, so they are usually automatically be put in the detention centres. These children did not have any proper legal assistance needed to apply for an asylum. Seeing the danger of detention centres, many experts believed that the option to be detained should only be used as a measure of last resort for these children (IOM, 2011). The lack of proper facilities for children in the detention centres also violates the Children's Rights as stated in the Convention of the Rights of the Child (UNICEF, 2017) where all children have the right to be protected from harm, obtain essential health care and education services, be with their families and have their best interests guide decisions that affect them. Improvements in urgently needed to provide better protection and treatment for these children, especially their social aspect since they are still in the crucial mental growth phase. And the strains that were caused by the risks faced by these children left them with greater risk because they lack the drive to set out in to the world (IOM, 2017).

One of the major actors that put a lot of attention to the welfare of refugee is the Holy See. The Holy See has specifically urged for an improvement on the protection of the rights of unaccompanied children on the move by making a formal remarks on the United Nations' Human Rights Council panel discussion on June 9, 2017 (Radio Vaticana, 2017). According to Archbishop Ivan Jurkovič, The Vatican's Permanent Observer to the UN in Geneva, the detention model for unaccompanied children on the move is wrong because these children do not have any control or responsible for the situations they are experiencing now. He added that by putting these children in the detention centre is the failure of international community to guarantee the fulfilment of these children's basic right. On the behalf of the Holy See, he appealed to the international community that the responsibility to protect the dignity and fundamental rights of each person, especially unaccompanied children, must be a primary consideration of all international communities. Furthermore, he added that in the case of unaccompanied children on the move, they must be considered as a child first and foremost and that their best interest must be a primary consideration.

In providing a better protection and treatment for those children, the Holy See is putting an emphasis on solidarity and shared responsibility. This emphasis is based on Pope John Paul II remarks made in 1981 on Refugee Crisis (Vatican.va, 2017a). He pointed out that refugee has always existed through the course of history, even stated in the holy Bible, as a result of tensions between different cultural and ethnic groups, and between individual right and the power of the state that led to war and persecution. Thus giving an individual, a choice of expulsion and flight. Detention centres, to him, is a place of individual and collective sufferings where people lost their dignity and meaning of life. Since it is often time overcrowded, detention centres was then transformed to be virtual prison. Refugees was almost always with no control of their destiny and found themselves at the mercy of others. This is why, the Holy See saw refugee crisis as a crisis of international community and the only 
INTERNATIONAL JOURNAL OF ACADEMIC RESEARCH IN BUSINESS AND SOCIAL SCIENCES

Vol. 9, No. 3, March, 2019, E-ISSN: 222 2-6990 @ 2019 HRMARS

way to solve this crisis, especially the case of unaccompanied children on the move, is through solidarity and shared responsibility among various international communities.

\section{Results}

To deal with the case of unaccompanied children on the move, the Holy See has been initiating various social dialogues, and cooperation on the international level by appealing to the conscience of the world. The Holy See is calling upon its local Churches and parish communities, as well as states, international institutions, international governmental and non-governmental organizations, religious associations and volunteers, and Episcopal conferences to broaden the scope of the initiatives (Vatican.va, 2017b). The Holy See points out that increasing interdependence among those entities is making it easier to share the responsibility, since it is not solely the destination states' responsibility to protect those children but also all of mankind sharing the same human dignity. The severity of the case of refugees and unaccompanied children over the recent year has been making it overwhelming for the destination state to deal with the situation alone. Take Turkey, Bulgaria, and Greece for example. Since the escalation of the Syrian conflict in 2014, more than 1,6 million children have fled to these 3 countries seeking for protection and since then has been causing serious financial and social problems for these 3 host countries (USCCB, 2015). To help these children and these 3 countries, the Holy See has asked for financial, as well as, humanitarian aids from the United States, the European Union and other nations in pursuit of a more durable solutions.

To ensure the more thorough protection and treatment for these children, the Holy See has also been working closely with various international organizations such as the UN (United Nations) and its specialized body, namely UNICEF (United Nations Children's Fund), UNHCR (United Nations High Commissioner for Refugees), and IOM (International Organization for Migration). The Holy See also have several religious non-governmental organizations (NGOs) to help organizing various dialogues, relief's distribution and creating networks of transnational civil society organizations working in the best interest of the unaccompanied children on the move. Several of its NGOs are ICMC (The International Catholic Migration Commission), and USCCB (United States Conference of Catholic Bishop) (USSCB, 2015; ICMC, 2015).

Other than a political entity, the Holy See also acts as a religious entity. The Holy See have a complex organizational hierarchy that allows the mobilization of its Churches and Parishes by the Pope as the highest leader. In September 2016, Pope Francis wrote a letter, drawing the international community's attention towards unaccompanied children on the move. This letter was addressed as a commemoration of the coming 2017 World Day of Migrant and Refugee (Vatican.va, 2017b). In order to do so, Pope Francis ordered that all Churches and Parishes, along with Parish's community to be more open in accepting and giving shelter to these children. Since then, more Churches in the United States, German, Great Britain and Ireland has accepted more of these children, as well as putting more pressure to the respective government to accept and welcome more unaccompanied child on the move (Schlein, 2017; Petre, 2017). In this letter, Pope Francis also assert the importance of cooperation with the other Churches (non-Catholic Churches), emphasizing on the same value taught held in the faith. Inter-religious cooperation is important in achieving the goal to put the children's right above all. 
Not just through Parishes and Churches, the Holy See also have a well organized network of organization in its body, working solely in the field of providing better protection and treatment in times of crisis, Caritas Internationalis. Caritas Internationalis is a confederation of over 160 members of almost every country in the world with the aim of helping the poor, vulnerable and excluded person, regardless of race or religion (Petre, 2017). It is a collective charitable organization consists of local charitable organizations, each under the leadership of the Bishop, that works with the support of the Roman Catholic Church as a whole. Being under the support of the Holy See, Caritas Internationalis also operates under the influence of the Pope and what is being emphasized at that time. Caritas Internationalis is one of the example how well managed is the structure of the Holy See. Through the intricate hierarchical and organizational chain of command in the Holy See's structure, the Holy See can act more effectively in providing a better protection and treatment for unaccompanied children on the move, as a transnational actor of both political entity and religious entity.

\section{Discussion}

The Holy See's commitment to provide a better protection and treatment for the unaccompanied children on the move can be seen through its consistent works as a political and religious entity in the world globally. The dual role of the Holy See is what makes its works unique and the Holy See itself is a unique transnational actor. Both as a political and religious entity, the Holy See has a unique form of transnationality [18]. As a political entity, the Holy See is regarded as a spiritual sovereign in the international politics arena. This means that according to the international law, the Holy See has full juridical status. And as a religious entity, the Holy See is considered a global empire of the Holy Roman Catholic Church.

As a global empire, the center of the Holy See is located in Rome under the Papacy, which makes the Pope as the highest leader (Vallier, 1971). Vatican as the capital of the Holy See coordinates and shapes the actions of the subsidiary field units (Churches) by giving general norms, symbolic leadership, and authoritative decisions. In relation to the center power, each Church then have a certain autonomy. This allows the Church to make demands on the center, to provide the center with new ideas, and also generate resources for the center, such as financial resources and services (skills and loyalties). Churches are connected with a vertical system with the Holy See as the center of power. This hierarchical structure and organizations has always been held by the Holy See since its establishment and its strict and discipline practice of the hierarchical order is one of the key that is making it possible to conduct a thorough global project. Orders given by the Pope is treated like the law that must be implemented in all of the Holy See's subsidiary fields unit.

The complexity of its internal features can also be seen while the Holy See is acting as a political entity (Vallier, 1971). The Holy See as a hierarchical system competes with other actors or autonomous centers of power in the terms of politics. To strengthen its political sovereignty, the Holy See was provided a territory in Rome, the State of the Vatican City as stated in the Lateran Treaty of 1929. With its permanent base, the Holy See can be seen to be a political sovereign, although it is still hard to characterized Vatican state as a nation state. Diplomacy is the only area outside of other area that has always been the main specialization of the Holy See's organizations. In the world politics, the Holy See took part in various intergovernmental activities with minimal decision making authority held by 
the Pope as the head of the state. In reality, as a sovereign, the Holy is still faced with the problems of legitimating itself and gaining access to national governments with political sovereignty because it is still considered, first and foremost, a religious organization. But nonetheless, its limited political and diplomatic role in the world politics are very important for its continuation on promoting its religious values.

The Holy See's religious and political role has always been in a constant change. This is caused by the ever changing form of connection and engagement of various actors in the world politics. Different types of issues and actions in the world politics require different types of action in the Holy See's religious and political system. The relations between the Church and the Center and between the Holy See with other world politics actors are very dynamic throughout the time. In the recent years, countries grew more secular, making the Holy See to realize the increasing importance of international organizations in representing its voice on critical issues (McKeegan, 2008). While working with and within the international organizations, the Holy See is practicing its political authority as a sovereign state guided by its religious beliefs that is highly influenced by the Papacy's religious authority as a compulsory guidance. This is what makes the Holy See's transnationality, a unique transnationality. The implementation of its policies is binding, both politically and religiously, especially to Catholics around the world.

The intricate yet entwined role of the Holy See's transnationality has always been proven effective in dealing with various humanitarian issues, such as the case of unaccompanied children on the move. The protection of these children's rights sometime requires a very intricate and appropriate juridical instrument and coordination mechanisms of various parts of international community. In the international political arena, interventions and solutions can be seen as violations of national sovereignty. This is why, in this regard, the Holy See cannot act solely as a political entity, but also as a religious entity which bind the international community regardless of their social and political systems. The Holy See plays an indirect role of mediation between different cultures and sociopolitical systems that allow people to better assume forms of behavior that favor social integration. Because of its social nature, it is not seen as a violations of national sovereignty and is hard to ignored, making it more effective approach in dealing with the case of unaccompanied children on the move.

\section{Conclusion}

Since the end of 2014, there has been a surge in the refugee migrations to the European region because of the increasing instability in the Middle East. An estimated 2, millions refugees are entering various countries in the European region seeking for asylum. $29 \%$ of them are children and approximately 176,000 of them are considered to be unaccompanied migrant children, children travelling without proper adult supervision. The record of unaccompanied children seeking asylum abroad has never been this high in history. These children are facing serious threats as they are the most vulnerable group of refugee without any legal authority over themselves. As a transnational actor, the Holy See has put more attention towards providing a better protection and treatment for these children. The Holy See's commitment towards the preservation of these children's dignity is based on solidarity and shared responsibility, appealing to the conscience of the international community. The Holy See's dual entity, both political and religious, gave the Holy See a unique form of transnationality to deal with sensitive issues such as in the case of unaccompanied children on the 
INTERNATIONAL JOURNAL OF ACADEMIC RESEARCH IN BUSINESS AND SOCIAL SCIENCES

Vol. 9, No. 3, March, 2019, E-ISSN: 222 2-6990 ¿ 2019 HRMARS

move. The Holy See plays an indirect role of mediation between different cultures and socio-political systems that that is socially binding. Its social nature is often time, not seen as a violations of national sovereignty and hard to ignored, making it a more effective approach in dealing with the case of unaccompanied children on the move

\section{Corresponding Author}

Maria Indira Aryani. Universitas Pembangunan Nasional "Veteran" Jawa Timur, Department of Internastional Relations, Faculty od Social and Political Sciences, Box.60294. Surabaya. Indonesia.

\section{References}

Caritas.org. (2017). Caritas Internationalis: Ending Poverty, Promoting Justice, and Restoring Dignity www.caritas.org.

European Commission, (2016). General Background Paper of the 10th European Forum on the Rights of the Child, 29-30 November 2016. Brussels: European Comission.

Eurostat, (2016). Eurostat News Release 44/2016. In Fullfacts, (2017). Asylum Seekers, the UK and Europe in https://fullfact.org/immigration/asylum-seekers-uk-and-europe/.

ICMC (International Catholic Migration Commission), (2015). 10\% of Refugees From Syria: Europe's Resettlement and Other Admission Responses in A Global Perspectives. Geneva: ICMC.

IOM (International Organization for Migration) and UNICEF (United Nations Children's Fund), (2017). Harrowing Journeys: Children and Youth on the Move Across the Mediterranean Sea, At Risk of Trafficking and Exploitation. New York: UNICEF.

IOM and UNICEF, (2015). IOM and UNICEF Data Brief: Migration of Children to Europe. New York: UNICEF.

McKeegan, T. (2008). Meet the New Generation of Catholic-Inspired NGOs in Catholiculture.org, April 2008 in https://www.catholicculture.org/culture/library/view.cfm?recnum=8187.

Petre, J. (2017). Senior Church Leaders Including Ex-Archbishop of Canterburry tell Theresa May to Welcome 400 Refugee Children to UK Before Calais Jungle Where They Are Trapped is Razed to The Ground|| in Dailymail.co.uk in http://www.dailymail.co.uk/news/article-3828702/Seniorchurch-leaders-tell-PM-welcome-400-refugee-children-UK.htm.

Vaticana, R. (2017). Holy See Denounces Detention of Migrant Children. In http://en.radiovaticana.va/news/2017/06/12/holy_see_denounces_detention_of_migrant_c hildren/1318404. 
Schlein, L. (2017). Catholic Church Calls for Local Parishes to Help Migrant and Refugee Children in https://www.voanews.com/a/catholic-church-calls-for-local-parishes-to-help-migrant-andrefugee-children/3767402.html.

UNICEF (2015). Refugee and Migrant Crisis Briefing Note November 2015. New York: UNICEF.

UNICEF (2017). A Child Is A Child: Protecting Children on the Move From Violence, Abuse and Exploitation. New York: UNICEF.

USCCB (United States Conference of Catholic Bishop) (2015). Refugee \& Hope in the Time of ISIS: The Urgent Need for Protection, Humanitarian Support, and Durable Situations in Turkey, Bulgaria, and Greece $\|$ in A Report of the Migration and Refugee Services of the United States Conference of Catholic Bishops, January 2015. Washington DC: USCCB.

Vallier, I. (1971). The Roman Catholic Church: A Transnational Actor in International Organization. Transnational Relations and World Politics, Vol 25, No. 3, Transnational Relations and World Politics (Summer, 1971). Wisconsin: University of Wisconsin Press

Vatican.va (2017) (a). Refugees: A Challenge to Solidarity. In Pontificial Council "Cor Unum" for the Pastoral Care of Migrants and Itinerant in http://www.vatican.va/roman_curia/pontifical_councils/corunum/documents/rc_pc_corunu m_doc_25061992_refugees_en.html.

Vatican.va (2017) (b). Child Migrants, the Vulnerable and the Voiceless. In Message of His Holiness Pope Francis for the World Day of Migrants and Refugees in https://w2.vatican.va/content/francesco/en/messages/migration/documents/papafrancesco_20160908_world-migrants-day-2017. 